\title{
Gangguan Hutan di KPH Kuningan Divisi Regional Jawa Barat dan Banten
}

\author{
Forest Disturbance at Forest Management Unit (KPH) Kuningan Division Regional West \\ Java and Banten
}

\author{
Ati Dwi Nurhayati ${ }^{1 *}$ dan Liana Arhami ${ }^{1}$
}

(Diterima Februari 2019/Disetujui November 2019)

\begin{abstract}
Forest protection is an effort to prevent and control the destruction of forests, forest areas, and forest products caused by human actions, livestock, fires, pests and diseases. The aims of this research are to identify the types of forest disturbance especially those caused by humans and physically, analyze the factors causing forest disturbance, and analyze efforts to control forest disturbance at KPH Kuningan. Forest disturbances that occurred in the KPH Kuningan during 2010-2014 included: timber theft, forest fires, forest encroachment, and natural disasters. The background of forest disturbance in the Kuningan KPH is mainly due to the socio-economic conditions of the community around the forest that are still low. Strategic actions taken to prevent forest disturbance at the KPH Kuningan are to take pre-emptive actions in the form of counseling and establish good relations between officers and the community through social communication and Community Based Forest Management (PHBM), preventive actions in the form of patrols and safeguards against forest potential, and repressive actions in the form of legal remedies against the perpetrators.
\end{abstract}

Key words: cause of forest disturbance, type of forest disturbance, forest disturbance control

\section{PENDAHULUAN}

Indonesia adalah negara kepulauan yang terdiri atas banyak pulau yang terhampar di garis khatulistiwa antara Lautan Hindia dan Samudera Pasifik yang diapit oleh dua benua yaitu Benua Asia dan Benua Australia. Letak geografis yang strategis menunjukkan betapa kaya Indonesia akan sumber daya alam. Sumber daya alam yang berasal dari kehutanan berupa hutan produksi, hutan lindung, hutan konservasi, kawasan suaka alam, kawasan pelestarian alam, taman buru, dan lain-lain yang memiliki berbagai fungsi penting bagi kehidupan berupa fungsi produksi, fungsi konservasi berupa penyangga kehidupan, wisata alam, dan jasa lingkungan, serta memiliki fungsi lindung sebagai pengatur tata air, pencegah banjir dan erosi, memelihara kesuburan tanah, pelestarian lingkungan hidup.

Keberadaan hutan di Indonesia saat ini sangat memprihatinkan akibat laju deforestasi dan degradasi yang sangat tinggi tiap tahunnya. Deforestasi dan degradasi yang terjadi akibat gangguan terhadap hutan, baik dari alam maupun perbuatan manusia. Gangguan hutan disebabkan oleh manusia berupa aktivitas pembalakan liar (illegal logging), kebakaran hutan,

\footnotetext{
${ }^{1}$ Departemen Silvikultur, Fakultas Kehutanan Institut

Pertanian Bogor

* Penulis korespondensi:

E-mail: awinur@yahoo.com
}

perambahan kawasan hutan, dan perladangan berpindah.

Upaya perlindungan hutan wajib dilakukan terhadap sumberdaya berupa hutan agar fungsi-fungsi penting hutan tetap berjalan secara optimal dan lestari. Menurut UU No. 41 tahun 1999 Tentang Kehutanan, yang dimaksud dengan perlindungan hutan adalah usaha untuk mencegah dan membatasi kerusakan hutan, kawasan hutan, dan hasil hutan yang disebabkan oleh perbuatan manusia, ternak, kebakaran, daya-daya alam, hama dan penyakit, serta mempertahankan hak-hak negara, masyarakat, dan perorangan atas hutan, kawasan hutan, dan hasil hutan, investasi serta perangkat yang berhubungan dengan pengelolaan hutan.

KPH Kuningan merupakan salah satu unit kerja pada Perhutani Divisi Regional Jawa Barat dan Banten yang mengalami kerugian finansial akibat gangguan hutan hampir setiap tahunnya. Informasi gangguan hutan dan faktor penyebabnya yang terjadi di kawasan KPH Kuningan sampai saat ini sangat terbatas, sehingga penelitian mengenai gangguan hutan pada kawasan KPH Kuningan perlu dilakukan untuk mendapatkan berbagai data dan informasi yang diperlukan dalam manajemen pengelolaan kawasan hutan KPH Kuningan untuk mengantisipasi semakin meluasnya kerusakan hutan di KPH Kuningan. Penelitian mengenai gangguan hutan KPH Kuningan di Kuningan, Jawa Barat ini bertujuan untuk (1) mengidentifikasi jenis-jenis gangguan hutan terutama yang disebabkan oleh manusia dan alam (2) menganalisis faktor-faktor penyebab gangguan hutan dan upaya pengendalian terhadap gangguan hutan. 


\section{METODE PENELITIAN}

\section{Waktu dan Lokasi Penelitian}

Penelitian ini dilaksanakan di Perhutani KPH Kuningan Divisi Regional Jawa Barat dan Banten pada bulan Maret 2015.

\section{Bahan dan Alat}

Bahan dan data yang diperlukan dalam penelitian ini adalah data gangguan hutan yang paling sering terjadi dan data curah hujan tahun 2010-2014 di lokasi penelitian. Alat-alat yang digunakan pada penelitian ini adalah pita meter, meteran jahit, tally sheet, lembar kuisioner sebagai interview guide saat wawancara, kamera digital, laptop, recorder, dan alat tulis.

\section{Prosedur Penelitian}

\section{Penentuan Lokasi Penelitian}

Lokasi penelitian ditentukan dengan menggunakan metode purposive sampling yaitu penelitian ini dilakukan pada lokasi hutan terganggu di sekitar hutan $\mathrm{KPH}$ Kuningan yang didasarkan pada tingkat gangguan dan aksesibilitas ke lokasi gangguan.

\section{Teknik Wawancara}

Wawancara adalah teknik pengambilan data melalui pertanyaan yang diajukan secara lisan kepada responden. Kuisioner adalah alat pengambilan data yang disusun oleh peneliti dalam bentuk tertulis, di dalamnya terdapat seperangkat pertanyaan dan atau pernyataan dan atau isian yang harus dijawab oleh rensponden (Irawanti 2008). Pemilihan responden ditentukan dengan menggunakan metode snowball sampling yaitu terlebih dahulu memilih responden yang dianggap dapat memberi informasi yang diperlukan (key informan), dan memiliki motivasi yang tinggi untuk bekerjasama (Silalahi 2012).

Penunjukan key informan dilakukan oleh ketua LMDH pada masing-masing desa yang telah ditentukan sebagai lokasi penelitian. Jumlah responden standar minimal penelitian survey dalam mengumpulkan informasi dari sampel atas populasi untuk mewakili seluruh populasi sebanyak 30 orang (Singarimbun et.al. 1995). Dengan demikian total responden yang diwawancarai untuk penelitian di 4 desa adalah 97 orang terdiri dari 30 responden di masing-masing Desa Tanjungkerta, Desa Sumurwiru, dan Desa Sukarapih BKPH Cibingbin. Adapun jumlah responden yang diwawancara di Desa Bantar Panjang BKPH Ciledug hanya sebanyak 7 orang karena kondisi yang tidak memungkinkan.

\section{Prosedur Analisis Data}

Metode analisis yang digunakan dalam pengolahan data wawancara yang berupa kuisioner adalah melalui analisis deskriptif. Analisis deskriptif merupakan cara analisis dengan mendeskripsikan atau menggambarkan data yang telah terkumpul tanpa membuat suatu kesimpulan umum atau generalisasi.

\section{KONDISI UMUM LOKASI PENELITIAN}

KPH Kuningan merupakan salah satu unit kerja pada Perum Perhutani Divisi Regional Jawa Barat dan Banten yang berkedudukan di Kota Kuningan, Jawa Barat. Secara geografis, wilayah hutan KPH Kuningan terletak pada $06^{\circ} 51^{\prime}-07^{\circ} 10^{\prime} \mathrm{LS}$ dan $108^{\circ} \mathrm{BB}-96^{\circ} \mathrm{BT}$. Wilayah hutan KPH Kuningan memiliki luas total sebesar $29 \quad 684.35$ Ha dan secara administratif pemerintahan masuk ke dalam dua wilayah yaitu: Kabupaten Kuningan dan Kabupaten Cirebon. Wilayah KPH Kuningan memiliki batas-batas antara lain: sebelah utara berbatasan dengan KPH Indramayu, Divisi Regional Jawa Barat dan Banten; sebelah timur berbatasan dengan KPH Balapulang, Divisi Regional Jawa Tengah; sebelah selatan berbatasan dengan KPH Ciamis, Divisi Regional Jawa Barat dan Banten; dan sebelah barat berbatasan dengan KPH Majalengka, Divisi Regional Jawa Barat dan Banten.

KPH kuningan terdiri dari 5 (lima) Bagian Kesatuan Pemangkuan Hutan (BKPH) dan 27 Resort Pemangkuan Hutan (RPH). Pembagian luas kawasan hutan KPH Kuningan menurut Bagian Kesatuan Pemangkuan Hutan (BKPH) yaitu: BKPH Waled seluas 3304.03 ha, BKPH Ciledug seluas 5931.54 ha, BKPH Cibingbin seluas 4738.68 ha, BKPH Luragung seluas 7941.42 ha, dan BKPH Garawangi seluas 7768.68 ha.

\section{HASIL DAN PEMBAHASAN}

Gangguan hutan berupa pencurian kayu dan kebakaran hutan terjadi hampir setiap tahun di Indonesia. Salah satunya di wilayah kawasan Perhutani. Pada Gambar 1 dapat dilihat bahwa kerugian finansial KPH Kuningan akibat gangguan hutan terdapat pada peringkat ke-3 setelah KPH Indramayu dan Sumedang yaitu sebesar Rp 708074 000. Kawasan hutan yang dikelola oleh Perhutani KPH Kuningan masih rawan dari gangguan hutan. Pada dasarnya faktor penyebab terjadinya gangguan hutan dibagi menjadi 3 yaitu faktor fisik atau alami (bencana alam), faktor biotik/hayati (hama dan penyakit), dan faktor manusia seperti pencurian kayu, kebakaran hutan dan perambahan kawasan hutan. Hal ini menyebabkan penurunan potensi sumber daya hutan cukup tajam sehingga menurunkan pendapatan negara dari kawasan hutan.

Pada Gambar 2 dapat dilihat bahwa gangguan hutan yang paling sering terjadi di KPH Kuningan adalah pencurian kayu dan kebakaran hutan. Pada KPH Kuningan, pencurian kayu merupakan gangguan hutan yang paling tinggi dibandingkan kebakaran hutan dan bencana alam, dengan rata-rata jumlah kejadian sebanyak 43 kali selama lima tahun terakhir ini. Kebakaran hutan menduduki peringkat kedua sebanyak 13 kali dan diikuti dengan bencana alam sebanyak 10 kali.

\section{Pencurian Kayu}

Pada Gambar 3 dapat dilihat bahwa frekuensi kejadian pencurian kayu di KPH Kuningan cenderung mengalami kenaikan setiap tahunnya. Frekuensi 
pencurian kayu paling tinggi di KPH Kuningan selama lima tahun terakhir ini terjadi pada tahun 2014 sebanyak 108 kali, sedangkan yang terendah terjadi pada tahun 2011 yaitu sebanyak 6 kali. Peningkatan kejadian pencurian kayu di KPH Kuningan di setiap tahunnya dapat disebabkan karena meningkatnya tingkat kebutuhan ekonomi masyarakat. Selain itu, diameter pohon mengalami peningkatan setiap tahunnya sehingga akan berdampak pada daya jual kayu yang semakin tinggi seiring bertambahnya diameter pohon.

Jenis kayu yang hilang akibat pencurian kayu di KPH Kuningan tahun 2010-2014 yaitu jati, sengon, rimba, pinus, mahoni, rimba campuran, dan sonobrit, dengan total kerugian secara finansial sebesar Rp 1588 506000 disajikan pada Tabel 1.

Kerugian finansial terendah yaitu pada tahun 2011 sebesar Rp 5907 000, hal ini dikarenakan jumlah kayu yang dicuri pada tahun 2011 tersebut lebih sedikit dibanding tahun lainnya yaitu sebanyak 26 pohon yang hilang. Adapun kerugian finansial tertinggi sebesar Rp 746038000 pada tahun 2013. Hal ini dikarenakan total jumlah kayu yang hilang paling banyak dibandingkan yang lainnya. Jenis kayu yang hilang adalah jenis rimba (38 pohon), mahoni (5 pohon) dan jenis kayu jati yang memiliki nilai jual tinggi yaitu sebanyak 755 pohon.
Pada Gambar 4 dapat dilihat bahwa frekuensi kejadian pencurian kayu selama 5 tahun terakhir berbeda-beda di setiap BKPH. BKPH Waled memiliki frekuensi pencurian kayu terendah yaitu sebanyak 2, sedangkan yang memiliki frekuensi tertinggi terjadi di BKPH Ciledug yaitu sebanyak 27. Hal ini disebabkan aksesibilitas di BKPH Ciledug lebih mudah dan dekat menuju ke hutan, mata pencaharian masyarakat yang masih tergantung pada hutan tergolong cukup tinggi, dan potensi tegakan Jati dengan diameter yang besar di BKPH Ciledug memiliki nilai jual yang tinggi. Hasil penelitian menunjukkan bahwa diameter tunggak rata-

Tabel 1 Kerugian finansial akibat pencurian kayu di KPH Kuningan tahun 2010-2014

\begin{tabular}{cc}
\hline Tahun & Kerugian Finansial \\
\hline 2010 & Rp 141860000 \\
2011 & Rp 5907000 \\
2012 & Rp 181731000 \\
2013 & Rp 746038000 \\
2014 & Rp 512970000 \\
\hline Total & Rp 1 588 506 000 \\
\hline
\end{tabular}

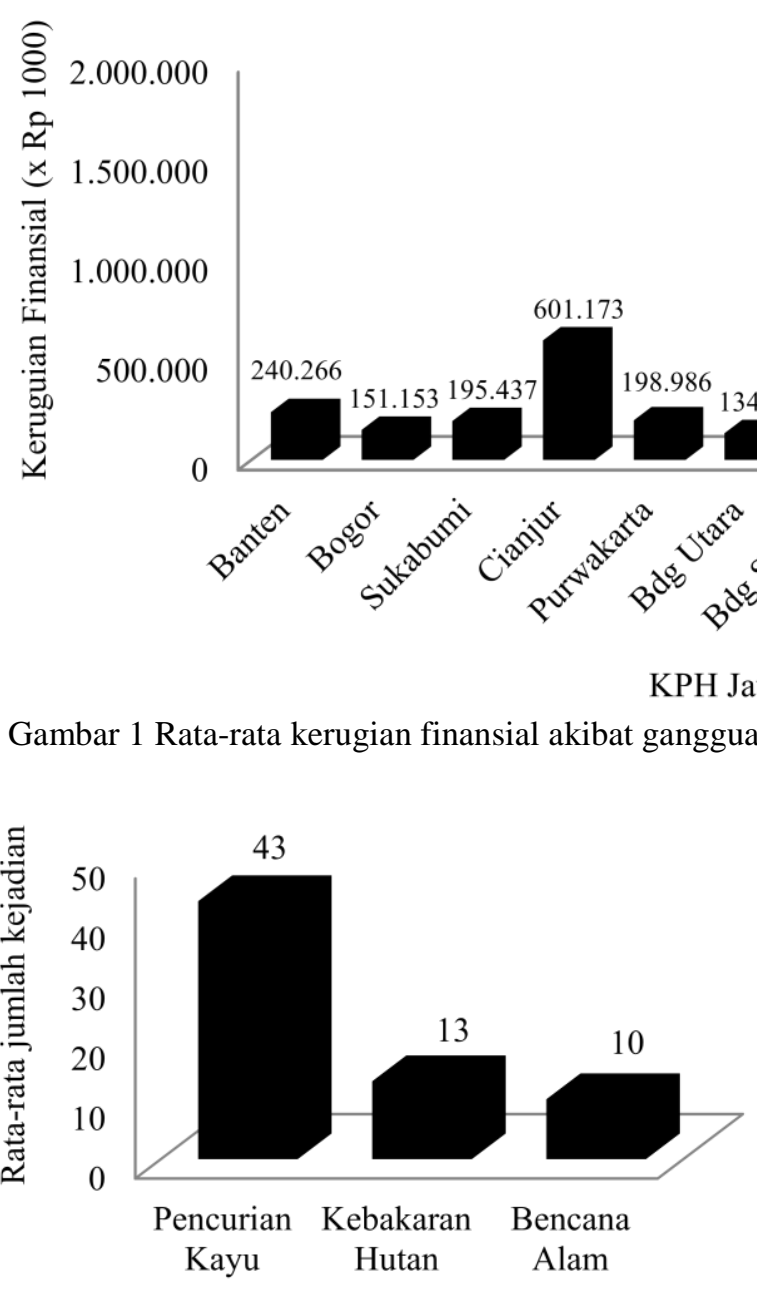

Gangguan Hutan di KPH Kuningan

Gambar 2 Rata-rata kejadian gangguan hutan di KPH Kuningan tahun 2010-2014



Gambar 3 Frekuensi pencurian kayu tahun 2010-2014 di KPH Kuningan 
rata pohon yang dicuri di RPH Bantar Panjang BKPH Ciledug yaitu $31 \mathrm{~cm}$ dari 10 pohon Jati yang dicuri pada petak $84 \mathrm{~F}, 25 \mathrm{~cm}$ dari 7 pohon (Petak 66a), $31 \mathrm{~cm}$ dari 22 pohon Jati (Petak $81 \mathrm{E}), 28 \mathrm{~cm}$ dari 10 pohon ( Petak $81 \mathrm{~b}), 25 \mathrm{~cm}$ dari 4 pohon (Petak $81 \mathrm{i}$ ).

\section{Kebakaran Hutan}

Kebakaran hutan merupakan gangguan terbesar kedua setelah pencurian kayu di KPH Kuningan. Pada Gambar 5 dapat dilihat bahwa rata-rata luas kebakaran hutan yang terjadi di KPH Kuningan tahun 2010-2014 cenderung meningkat walaupun tidak stabil. Tahun 2010 merupakan prestasi bagi KPH Kuningan karena pada tahun ini tidak terjadi kebakaran hutan di wilayah KPH Kuningan. Hal ini dikarenakan intensitas curah hujan di tahun 2010 sangat tinggi. Menurut Syaufina (2008) curah hujan merupakan unsur iklim yang memiliki korelasi tinggi dalam menentukan akumulasi bahan bakar, dimana frekuensi dan luas kebakaran tertinggi terjadi pada bulan dengan curah hujan yang rendah (kurang dari $60 \mathrm{~mm}$ ). Jika curah hujan tinggi maka kelembaban akan tinggi sehingga kejadian kebakaran akan lebih sulit terjadi.

KPH Kuningan mengalami kebakaran hutan di tahun 2011 seluas 40.65 ha lahan terbakar, dan pada tahun 2012 seluas 38.95 ha. Pada tahun 2013 merupakan kejadian kebakaran hutan yang paling besar selama 5 tahun terakhir ini, dengan rata-rata luas lahan yang terbakar sebesar 101.3 ha. Kejadian kebakaran hutan selama tahun 2010-2014 di KPH Kuningan tertinggi terjadi pada bulan September dan Oktober. Menurut Pratiwi (2007) saat memasuki musim kemarau yang biasanya berlangsung mulai pertengahan Juli hingga akhir Oktober sering terjadi bulan kering yang rawan terjadinya kebakaran hutan. Luas lahan terbakar di tahun 2014 mengalami penurunan kembali yaitu menjadi 61.65 ha. Hal ini menunjukkan bahwa pihak Perhutani KPH Kuningan telah berupaya untuk mengendalian kebakaran hutan pada tahun sebelumnya.

Jenis tanaman yang terbakar akibat kebakaran hutan KPH Kuningan yaitu jenis sengon, mahoni, pinus, dan jati. Jenis Pinus dan Jati merupakan jenis yang paling sering terbakar. Hal ini dikarenakan jenis pinus dan jati

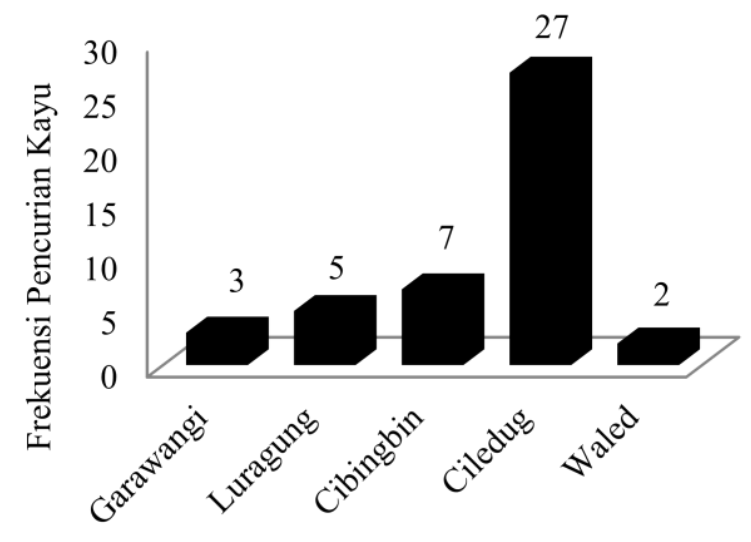

BKPH di KPH Kuningan

Gambar 4 Frekuensi pencurian kayu selama tahun 2010-2014 pada setiap BKPH di KPH Kuningan

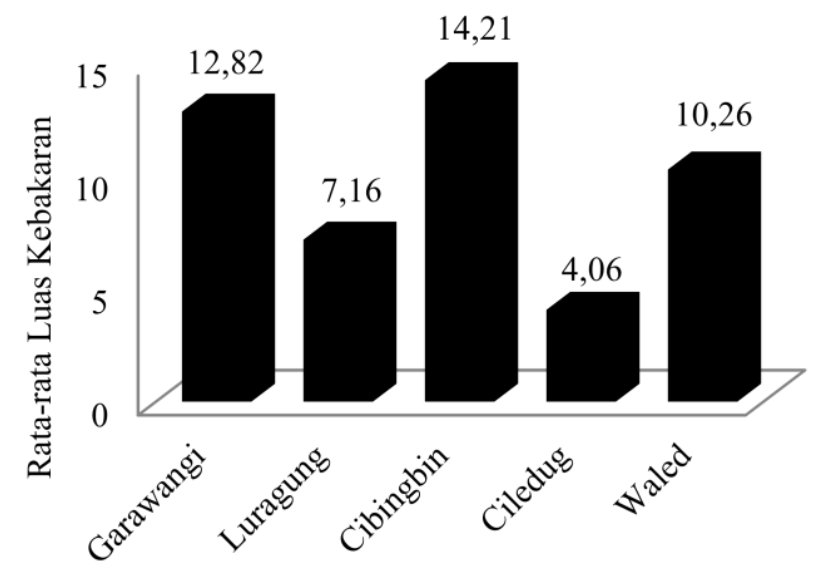

BKPH di KPH Kuningan

Gambar 6 Rata-rata luas kebakaran hutan pada setiap BKPH di KPH Kuningan selama 5 tahun Terakhir

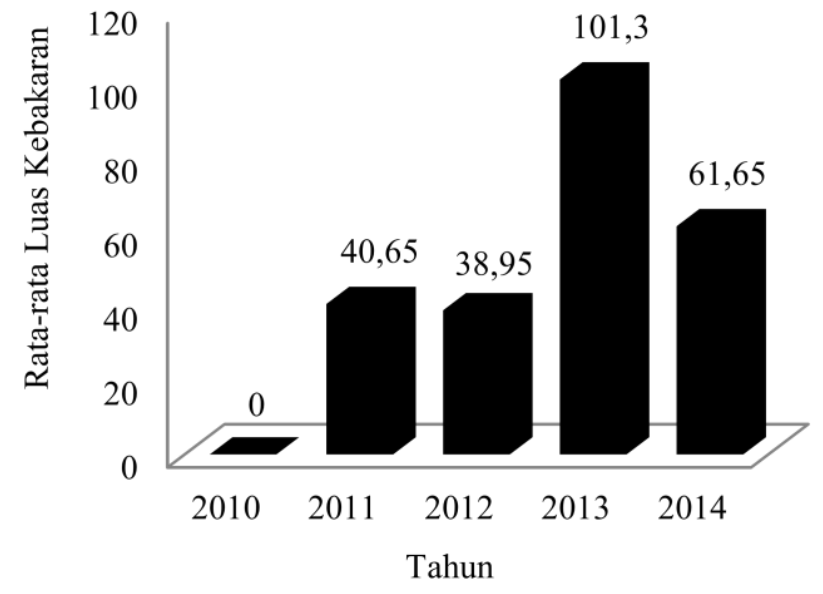

Gambar 5 Rata-rata luas kebakaran hutan di KPH Kuningan tahun 2010-2014

Tabel 2 Kerugian finansial akibat kebakaran hutan di KPH Kuningan tahun 2010-2014

\begin{tabular}{|c|c|c|}
\hline Tahun & Kerugian Finansial & $\begin{array}{c}\text { Jenis Pohon } \\
\text { Terbakar }\end{array}$ \\
\hline 2010 & 0 & - \\
\hline 2011 & Rp 147188000 & $\begin{array}{c}\text { Sengon } \\
\text { Mahoni } \\
\text { Pinus }\end{array}$ \\
\hline 2012 & Rp 140062000 & $\begin{array}{c}\text { Jati } \\
\text { Pinus }\end{array}$ \\
\hline 2013 & Rp 318037000 & $\begin{array}{c}\text { Jati } \\
\text { Pinus }\end{array}$ \\
\hline 2014 & Rp 175088000 & $\begin{array}{l}\text { Mahoni } \\
\text { Jati } \\
\text { Pinus } \\
\text { Mahoni }\end{array}$ \\
\hline
\end{tabular}

Total Rp 780375000 
sebagai tanaman pokok yang ditanam di lahan hutan KPH Kuningan. Selain itu, sifat pinus sendiri yang mengandung resin sehingga lebih mudah untuk terbakar.

Kerugian total finansial selama 5 tahun terakhir akibat kebakaran hutan (Tabel 2) dihitung berdasarkan luasan hutan yang terbakar, jenis tegakan yang ditanam dan umur tanaman pada tegakan yaitu sebesar Rp 780 375 000. KPH Kuningan tidak mengalami kebakaran hutan pada tahun 2010. Kerugian finansial tertinggi terjadi pada tahun 2013 sebesar Rp 318037 000, hal ini dikarenakan kebakaran hutan tertinggi pada tahun tersebut dan jenis tanaman yang terbakar yaitu jenis pinus dan jati.

Kebakaran hutan selama 5 tahun terakhir terjadi pada setiap BKPH di KPH Kuningan tersebut disajikan pada Gambar 6. Dapat dilihat bahwa rata-rata luas kebakaran hutan tertinggi di KPH Kuningan selama tahun 2010-2014 yaitu BKPH Cibingbin dengan luas kebakaran sekitar 14.21 ha, diikuti dengan BKPH Garawangi sekitar $12.82 \mathrm{Ha}$, BKPH Waled sekitar 10.26 Ha, dan BKPH Luragung sekitar 7.16 Ha. BKPH Ciledug merupakan BKPH dengan rata-rata luas lahan yang terbakar paling rendah yaitu $4.06 \mathrm{Ha}$. Hal ini dikarenakan tegakan yang terdapat di BKPH Ciledug berupa tegakan jati dengan diameter yang besar sehingga sulit untuk terbakar.

Tingginya luas kebakaran hutan di BKPH Cibingbin dikarenakan adanya aktivitas masyarakat yang membakar ranting, sampah di kawasan hutan dan kemudahan akses untuk mencapai hutan. Adapun luas kebakaran di BKPH Garawangi merupakan peringkat 2, hal ini dikarenakan keadaan topografi yang berombak dan berbukit sehingga api dapat lebih mudah menjalar dengan cepat. Kebakaran sering terjadi pada lokasi yang memiliki topografi berombak (Sulinda 2003). Tipe kebakaran hutan di KPH Kuningan ini mengkonsumsi bahan bakar yang terdapat di lantai hutan seperti serasah, jatuhan ranting, dan tumbuhan bawah.

\section{Perambahan Kawasan Hutan}

Berdasarkan hasil wawancara dan analisis di lapangan, perambahan kawasan hutan di KPH Kuningan yang salah satunya terjadi di BKPH Cibingbin RPH Cileuya yang berada di petak $22 \mathrm{~F}$ dengan luas konflik

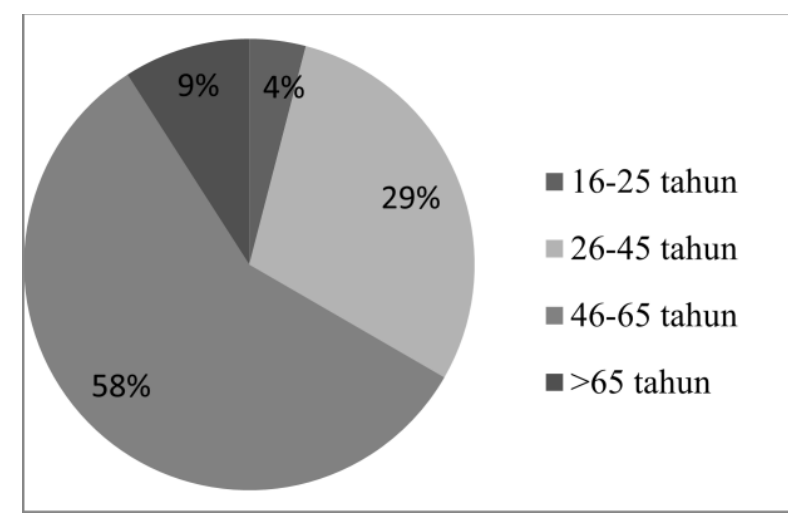

Gambar 7 Distribusi sebaran kelompok umur desa penelitian lahan 35.05 Ha. Pada tahun 2010 telah dilakukan penyelesaian oleh pihak KPH Kuningan, seluas 17.93 Ha diambil alih kembali oleh pihak Perhutani untuk dikembalikan menjadi kawasan hutan dengan ditanami tanaman jenis Jati JPP tahun 2011 dan 2012, sedangkan sisanya seluas 17.12 Ha tetap dijadikan pemukiman oleh masyarakat Desa Jabranti Kecamatan Karang Kancana. Upaya penyelesaian konflik tenurial yang dilakukan oleh pihak Perhutani dengan melakukan pertemuan langsung terus menerus dengan masyarakat dan menyelesaikan sengketa tanah dengan melibatkan instansi yang terkait.

\section{Karakteristik Responden}

Pemilihan lokasi penelitian berdasarkan pada kejadian gangguan hutan yang tertinggi, yang dalam hal ini adalah kebakaran hutan dan pencurian kayu. Berdasarkan hal tersebut maka terpilih tiga desa yaitu Desa Tanjungkerta, Desa Sumurwiru, dan Desa Sukarapih BKPH Cibingbin. Adapun jumlah responden sebanyak 30 orang pada setiap desa. BKPH Cibingbin mengalami kejadian kebakaran hutan tertinggi dan kejadian pencurian kayu kedua di KPH Kuningan. Selain itu wawancara juga dilakukan di Desa Bantar Panjang BKPH Ciledug dengan kasus pencurian kayu tertinggi di KPH Kuningan. Jumlah responden yang diwawancara di Desa ini hanya sebanyak 7 orang. Hal ini dikarenakan sulitnya masyarakat dalam bekerja sama. Analisis kuisioner dari demografi berupa umur, pendidikan, mata pencaharian, pendapatan, dan aksesibilitas.

\section{Umur}

Kelompok umur 15-64 tahun merupakan umur produktif yang secara ekonomis sudah tidak tergantung orang tua atau orang lain yang menanggungnya dalam memenuhi kebutuhan (BkkbN 2013). Kelompok umur responden digolongkan menjadi empat kelompok yaitu 16-25 tahun, 26-45 tahun, 46-65 tahun dan lebih dari 65 tahun. Pada Gambar 7 dapat dilihat bahwa persentase kelompok umur produktif yang menjadi responden dari tiap desa penelitian sebagian besar tergolong dalam kelompok umur 46-65 tahun sebesar $57 \%$ dan 26-45 tahun sebesar $29 \%$. Hal ini menunjukkan responden keempat desa penelitian tergolong dewasa dan dapat merespon jawaban pertanyaan dalam penelitian.

\section{Tingkat Pendidikan}

Hasil penelitian menunjukkan bahwa sebagian besar masyarakat desa penelitian memiliki tingkat pendidikan formal yaitu tamat Sekolah Dasar. Persentasi tingkat pendidikan SD masing-masing desa penelitian yaitu Desa Tanjungkerta sebesar 96.67\%, Desa Sukarapih sebesar $93.33 \%$, Desa Sumurwiru sebesar $76.67 \%$, dan Desa Bantar Panjang 57.14\%. Sedangkan tingkat pendidikan paling sedikit yaitu lulusan Sekolah Menengah Atas (SMA) sebesar 3\% untuk Desa Sumurwiru. Hal ini menunjukkan bahwa tingkat pendidikan di desa penelitian tersebut tergolong rendah karena menurut Peraturan Pemerintah Republik 
Indonesia No 47 Tahun 2008 tentang wajib belajar di Indonesia yaitu selama 9 (sembilan) tahun pada jenjang pendidikan dasar, yaitu dari tingkat kelas 1 Sekolah Dasar (SD) atau Madrasah Ibtidaiyah (MI) hingga kelas 9 Sekolah Menengah Pertama (SMP) atau Madrasah Tsanawiyah (MTs). Rendahnya pendidikan tersebut dapat dikarenakan tingginya biaya pendidikan dan rendahnya kesadaran masyarakat akan pentingnya tingkat pendidikan, sehingga akan mempengaruhi pola pikir masyarakat dalam bertindak dan mangambil keputusan yang lebih berorientasi jangka pendek.

\section{Mata Pencaharian}

Mata pencaharian masyarakat di desa penelitian (Desa Sukarapih, Desa Sumurwiru, Desa Tanjungkerta dan Desa Bantarpanjang) sebagian besar berprofesi sebagai petani yaitu sebanyak 81 jiwa, buruh sebanyak 10 jiwa, wirausaha 4 jiwa, dan wiraswasta serta pensiunan masing-masing 1 jiwa. Masyarakat dengan mata pencaharian tersebut biasanya memiliki pekerjaan lain seperti mencari rumput.

\section{Kondisi Sosial Ekonomi Masyarakat}

Berdasarkan hasil wawancara, tingkat pendapatan masyarakat digolongkan menjadi tiga yaitu pendapatan kurang dari Rp 400 000, Rp 400000 - Rp 800 000, dan lebih dari Rp 800 000. Hasil penelitian menunjukkan bahwa masyarakat yang menjadi responden dengan tingkat pendapatan lebih dari Rp 800000 tersebar di Desa Sumurwiru sebanyak 60\% dan Desa Bantar Panjang sebanyak 57.14\%. Sedangkan Desa Tangjungkerta sebanyak $46.67 \%$ dan Desa Sukarapih sebanyak $60 \%$ memiliki sebaran distribusi responden berdasarkan tingkat pendapatan yang berkisar antara Rp 400000 - Rp 800 000. Tingkat pendapatan keempat desa penelitian tersebut tergolong rendah karena masih dibawah Upah Minimum Kabupaten (UMK) Kuningan yaitu sebesar Rp 1206000 per bulan.

\section{Aksesibilitas}

Penentuan daerah rawan gangguan hutan berdasarkan aksesibilitas dibagi menjadi dua kriteria yaitu jarak tempuh ke hutan dan aksesibilitas menuju ke hutan. Hasil penelitian menunjukkan bahwa setiap desa penelitian memilik jarak yang bervariasi antara pemukiman masyarakat dengan hutan milik KPH Kuningan yaitu kurang dari $1 \mathrm{~km}$, berkisar antara $1-2$ $\mathrm{km}$, dan lebih dari $2 \mathrm{~km}$. Jarak pemukiman masyarakat Desa Tanjungkerta menuju hutan tergolong lebih jauh dibandingkan dengan desa lainnya yaitu $70 \%$ untuk jarak tempuh lebih dari $2 \mathrm{~km}$, dan $30 \%$ untuk jarak antara $1-2 \mathrm{~km}$. Persentase jarak tempuh ke hutan di Desa Sukarapih adalah $80 \%$ untuk jarak $1-2 \mathrm{~km}$, sebesar $6.67 \%$ berjarak kurang dari $1 \mathrm{~km}$, dan $13.33 \%$ berjarak lebih dari $2 \mathrm{~km}$. Sedangkan Desa Bantar Panjang dan Sumurwiru memiliki persentase tertinggi pada jarak kurang dari $1 \mathrm{~km}$ menuju hutan yaitu sebesar $71.43 \%$ dan $86.67 \%$. Kedekatan jarak antara pemukiman dengan hutan diduga dapat menjadi faktor sering terjadinya gangguan hutan.

\section{Upaya Pengendalian Gangguan Hutan di KPH Kuningan}

Berdasarkan hasil wawancara dengan KPH Kuningan dapat disimpulkan bahwa tindakan strategis yang dilakukan untuk mencegah terjadinya gangguan hutan yang terjadi di KPH Kuningan adalah: melakukan tindakan pre-emtif, tindakan preventif, dan tindakan represif. Tindakan pre-emtif yang dilakukan berupa penyuluhan serta menjalin hubungan yang baik antara petugas dan masyarakat dengan melalui komunikasi sosial dan PHBM. Tindakan preventif yang dilakukan berupa patroli dan penjagaan terhadap potensi hutan KU I dan KU II-Up. Tindakan represif yang dilakukan berupa upaya hukum terhadap para pelaku. Selain itu dilakukan patroli rutin, patroli gabungan, Polhut mempunyai mitra binaan berupa LMDH terutama untuk daerah yang agak rawan. Polhut dibagi menjadi 2 yaitu: Polhutmob (se-KPH) yang dipimpin oleh seorang Komandan Regu (Danru) dan Polter (wilayah RPH).

Tujuan upaya penanganan terhadap masalah gangguan hutan yang terjadi di KPH Kuningan yaitu untuk menekan laju penurunan potensi sumberdaya hutan. Upaya penanganan kebakaran hutan dapat dilakukan dengan memberikan pembinaan terhadap masyarakat dan penguatan kelembagaan desa hutan dilakukan secara periodik, dan modifikasi mobil Polhut (memasang water torn) untuk mempercepat penanganan kebakaran dan melakukan patroli secara rutin. Kegiatan patroli kebakaran hutan terutama dilakukan pada tanaman yang muda karena tergolong masih rentan yaitu untuk tanaman jati umur 5 tahun ke bawah, untuk tanaman jenis rimba baik umur tanaman muda dan tua harus diantisipasi dari kebakaran karena penanganan kebakaran jenis kayu rimba lebih sulit daripada jati karena medannya lebih sulit ditempuh, dan melakukan jadwal piket yang digabung dari beberapa RPH untuk memonitor dan menangani kebakaran.

Upaya penanganan pencurian kayu yaitu penugasan tenaga pengamanan hutan disesuaikan dengan tingkat kerawanan wilayah berdasarkan pemetaan tingkat kerawanan hutan per RPH, pembinaan terhadap masyarakat desa hutan secara rutin. Upaya yang dapat dilakukan untuk menangani masalah perambahan kawasan hutan yaitu dengan melakukan patroli rutin terhadap kawasan hutan.

\section{SIMPULAN DAN SARAN}

\section{Simpulan}

Jenis-jenis gangguan hutan yang terjadi di KPH Kuningan selama 5 (lima) tahun terakhir (2010-2014) antara lain: pencurian kayu, kebakaran hutan, bencana alam dan konflik tenurial. Gangguan hutan yang sering terjadi di KPH Kuningan adalah pencurian kayu dan kebakaran hutan. Faktor penyebab terjadinya gangguan hutan di KPH Kuningan adalah karena faktor manusia. Upaya yang dilakukan oleh KPH Kuningan untuk mencegah terjadinya gangguan hutan adalah: melakukan tindakan pre-emtif, tindakan preventif, dan tindakan represif. 


\section{Saran}

Pendekatan melalui komunikasi sosial kepada masyarakat secara aktif sebagai tindakan pre-emtif perlu lebih ditingkatkan dan meningkatkan partisipasi masyarakat untuk mencegah gangguan hutan di KPH Kuningan. Monitoring dalam pengawasan potensi hutan dan evaluasi di wilayah KPH Kuningan perlu ditingkatkan kembali agar dapat meminimalisir gangguan hutan sehingga kerugian secara fisik maupun finansial dapat dikurangi. Selain itu, perlu penegakan hukum yang tegas terhadap para pelaku penyebab gangguan hutan.

\section{DAFTAR PUSTAKA}

Departemen Kehutanan. 1999. Undang- Undang Republik Indonesia Nomor 41 Tahun 1999 tentang Kehutanan. Jakarta(ID) : Departemen Kehutanan.

KPH Kuningan. 2010. Laporan Kejadian Gangguan Keamanan Hutan di KPH Kuningan s.d Desember 2010. Kuningan (ID): KPH Kuningan.

KPH Kuningan. 2011. Laporan Kejadian Gangguan Keamanan Hutan di KPH Kuningan s.d Desember 2011. Kuningan (ID): KPH Kuningan.
KPH Kuningan. 2012. Laporan Kejadian Gangguan Keamanan Hutan di KPH Kuningan s.d Desember 2012. Kuningan (ID): KPH Kuningan.

KPH Kuningan. 2013. Laporan Kejadian Gangguan Keamanan Hutan di KPH Kuningan s.d Desember 20103 Kuningan (ID): KPH Kuningan.

KPH Kuningan. 2014. Laporan Kejadian Gangguan Keamanan Hutan di KPH Kuningan s.d Desember 2014. Kuningan (ID): KPH Kuningan.

Irawanti S. 2008. Improvisasi Teknik Wawancara dalam Penelitian Sosial Ekonomi. Volume ke-8. Bogor (ID) : Badan Penelitian dan Pengembangan Kehutanan.

Silalahi U. 2012. Metode Penelitian Sosial. Bandung (ID) : PT.Refika Aditama.

Singarimbun, Masri, Sofian E. 1995. Metode Penelitian Survei. Jakarta(ID): LP3S.

Sulinda L. 2003. Strategi pengendalian kebakaran hutan secara terpadu di KPH Semarang PT Perhutani Unit I Jawa Tengah [skripsi]. Bogor (ID): Fakultas Kehutanan Institut Pertanian Bogor.

Syaufina L. 2008. Kebakaran Hutan dan Lahan di Indonesi: Perilaku Api, penyebab, dan Dampak Kebakaran. Malang(ID) : Bayumedia Publishing. 